\title{
GAMBARAN PENGETAHUAN SISWA TENTANG ROKOK DAN BAHAYANYA DI SMA PETRA SAWANG JAUH KECAMATAN KENDAHE
}

\author{
STUDENT KNOWLEDGE ABOUT CIGARETTE AND \\ THE EFFECT IN SMA PETRA SAWANG JAUH KECAMATAN KENDAHE
}

\author{
Melanthon Umboh, Gitalia Putri Medea \\ Program Studi Keperawatan Jurusan Kesehatan Politeknik Negeri Nusa Utara \\ Email: melanthon.umboh@gmail.com
}

\begin{abstract}
Abstrak: Merokok sudah menjadi tren dikalangan banyak orang dimasyarakat tidak lepas juga anak remaja. SMA Petra Sawang Jauh merupakan salah satu SMA di kecamatan Kendahe yang ada di Kabupaten Kepulauan Sangihe. Meskipun letak sekolah tersebut jauh dari pusat kota tetapi akses untuk mendapatkan rokok tersedia baik di toko kecil atau warung-warung dan tempat penjualan lainnya, akibatnya siapapun yang mau dapat mengkonsumsi rokok dengan mudah. Pengetahuan tentang rokok merupakan hal yang penting harus ada pada seorang individu sebab beberapa penelitian menemukan pengetahuan yang baik akan mengurangi angka kejadian merokok. Tujuan dari penelitian ini yaitu mengetahui gambaran pengetahuan siswa tentang rokok dan bahayanya di SMA Petra Sawang Jauh Kecamatan Kendahe. Penelitian ini merupakan jenis penelitian kuantitatif dengan metode deskriptif. Pengambilan sampel menggunakan purposive sampling yang memenuhi kriteria inklusi dan eksklusi. Jumlah sampel 96 orang siswa. Instrumen yang digunakan dalam penelitian ini yaitu kuesioner pengetahuan tentang rokok dan bahayanya. Hasil pada penelitian ini ditemukan sebesar $78,13 \%$ siswa memiliki pengetahuan baik, 20,83\% siswa memiliki pengetahuan cukup dan 1,04\% memiliki pengetahuan kurang. Kesimpulan pengetahuan siswa tentang rokok dan bahayanya di SMA Petra Sawang Jauh berada pada kategori baik. Saran bagi guru-guru di sekolah agar memberikan pendidikan kesehatan terkait rokok.
\end{abstract}

Kata kunci: Rokok, pengetahuan, kendahe.

\begin{abstract}
Abtract: Smoking has become a trend among many people in society including teenagers. Petra Sawang Jauh Senior High School is one of the secondary school in Kendahe Subdistrict in Sangihe Island Regency. Even though the location of the school was far from the city center, access to cigarettes was available both in small shops or stalls and other places of sale, consequently anyone who wants to smoke can consume cigarettes easily. Knowledge about cigarettes was important thing that must exist in a person because researcher found good knowledge will reduce the incidence of smoking. The purpose of the study was to describe students knowledge about cigarettes and the effect to Student in Petra Sawang Kendahe Subdistrict. The method in this research was a quantitative research with descriptive method. Take a sample with purposive sampling that has inclusion and exclusion criteria. The number of research samples was 96 students. The instrument of this study was the questionnaire cigarettes knowledge and the effect. The results of this study found $78.13 \%$ students had good knowledge, $20.83 \%$ students had sufficient knowledge and $1.04 \%$ had less knowledge. Conclusion student knowledge about cigarettes and dangers in Petra Sawang Jauh High School were in the good category. Suggestion for teachers in school to provide health education related cigarettes.
\end{abstract}

Keyword: Cigarettes, knowledge, kendahe.

\section{PENDAHULUAN}

Rokok adalah silinder dari kertas yang memiliki ukuran panjang 70 sampai dengan $120 \mathrm{~mm}$ (bervariasi) dengan diameter kurang lebih 10 mm (Fajar, 2011).
Menurut Badan Narkotika Nasional Republik Indonesia (2013) rokok termasuk ke dalam definisi narkoba dimana narkoba memuat 3 kelompok zat aktif yaitu Narkotika, Psikotropika dan Bahan 
Adiktif lainnya, rokok bersama dengan alkohol termasuk ke dalam kelompok bahan adiktif lainnya.

Data statistik menunjukkan bahwa $90 \%$ kematian akibat gangguan pernapasan, $25 \%$ kematian akibat penyakit jantung koroner dan $75 \%$ kematian akibat penyakit emphysema kesemuanya itu dipicu dari kebiasaan merokok (Husaini,2007). Hal ini dapat dilihat berdasarkan hasil Riskesdas 2018 dimana terjadi peningkatan prevalensi merokok. Prevalensi merokok pada usia 10-18 tahun mengalami peningkatan yaitu dari 7,2\% tahun 2013 menjadi 9,1\% tahun 2018 (Badan Penelitian dan Pengembangan Kesehatan, 2018)

Merokok sudah menjadi tren dikalangan banyak orang di masyarakat tidak lepas juga anak remaja. Di kabupaten kepulauan Sangihe hampir pada setiap area terbuka, tempat umum dan layanan publik akan dengan mudah kita temukan orang merokok, dari anak-anak yang masih menggunakan seragam SMP sampai dengan orang dewasa (Dinas Kesehatan Kabupaten Kepulauan Sangihe, 2017). Abdullah \& Sudjarwo (2006) dalam Chandra (2014) mengungkapkan bahwa akibat sering dan banyak merokok berarti kerusakan jaringan otak sedemikian kronisnya yang telah diderita anak sekolah saat ini yang berefek terganggunya cara berpikir dan menangkap pelajaran di kelas sampai dengan timbul kemalasan dalam belajar, yang akhirnya nilai yang didapat dari guru di sekolah mengalami penurunan dari hari ke hari.

SMA Petra Sawang Jauh merupakan salah satu SMA di kecamatan Kendahe yang ada di Kabupaten Kepulauan Sangihe. Meskipun letak sekolah tersebut jauh dari pusat kota tetapi akses untuk mendapatkan rokok tersedia baik di toko kecil atau warung-warung dan tempat penjualan lainnya, akibatnya siapapun yang mau dapat mengkonsumsi rokok dengan mudah. Penelitian kuantitatif dan kualitatif yang dilakukan oleh Widati (2013) menyimpulkan bahwa pesan kesehatan yang tertera pada bungkus rokok belum efektif dalam meningkatkan pengetahuan dan pencegahan perilaku merokok para informan.
Doppy et al (2016) melakukan penelitian yang bertujuan menentukan hubungan antara pengetahuan tentang rokok dan kejadian merokok pada pelajar SMPN 1 Pariaman. Penelitian dengan jumlah responden 228 ini memperoleh hasil bahwa pengetahuan baik sebesar $60 \%$ dan kejadian merokok sebesar $1 \%$. Berdasarkan analisis statistik penelitian Doppy et al (2016) menunjukkan bahwa terdapat hubungan antara pengetahuan tentang rokok dan kejadian merokok pada pelajar SMPN 1 Pariaman.

Pengetahuan merupakan faktor predisposisi yang memengaruhi perilaku seseorang, mereka yang berpengetahuan tinggi diharapkan berperilaku positif (Rahmat et al, 2013). Meskipun demikian, hasil penelitian Rahmat et al (2013) menemukan pengetahuan tentang rokok bukan merupakan prediktor perilaku merokok pada perokok remaja. Sebab, pengetahuan mereka tentang merokok berada pada kategori tinggi $(83,4 \%)$. Penelitian Rahmat et al (2013) menemukan bahwa teman sebaya dan iklan rokok berpengaruh paling bermakna pada perilaku rokok remaja. Akan tetapi, Shabir et al (2013) menemukan bahwa pada remaja yang memiliki tingkat pengetahuan tentang bahaya merokok pada kategori baik, sebagian besar remaja tersebut tidak pernah melakukan tindakan merokok.

Maseda, Baithesda \& Djon (2013) dalam penelitiannya mengemukakan bahwa memiliki pengetahuan yang baik dan sikap positif mengakibatkan seseorang tidak mudah terpengaruh akan obyek disekitarnya dan akan memiliki pengaruh yang baik dalam waktu yang lama. Hal yang sama juga bagi kehidupan remaja yaitu mereka tidak akan mudah terpengaruh terhadap perilaku merokok jika memiliki pengetahuan dan sikap yang positif terhadap bahaya merokok (Maseda, Baithesda \& Djon, 2013).

Pengetahuan tentang rokok merupakan hal yang penting harus ada pada seorang individu sebab terdapat penelitian yang menemukan bahwa pengetahuan yang baik akan mengurangi angka kejadian merokok. Penelitian terkait pengetahuan tentang bahaya merokok masih minim di Kabupaten Kepulauan Sangihe 
khususnya pada para remaja di SMA Petra Sawang Jauh. Sehingga melakukan penelitian terkait pengetahuan remaja tentang bahaya rokok diharapkan menjadi langkah awal yang dapat digunakan sebagai panduan dalam penelitian selanjutnya. Oleh sebab itu, berdasarkan fenomena yang telah dipaparkan maka penulis perlu melakukan penelitian terkait Gambaran Pengetahuan Siswa Tentang Rokok dan Bahayanya di SMA Petra Sawang Jauh Kecamatan Kendahe.

Tujuan dari penelitian ini yaitu diketahuinya gambaran pengetahuan siswa tentang rokok dan bahayanya di SMA Petra Sawang Jauh Kecamatan Kendahe. Penelitian ini diharapkan dapat memberikan wawasan tentang gambaran pengetahuan siswa tentang rokok dan bahayanya di SMA Petra Sawang Jauh Kecamatan Kendahe, menambah referensi terkait pengetahuan siswa tentang rokok dan bahayanya di SMA Petra Sawang Jauh Kecamatan Kendahe dan diharapkan menjadi acuan dalam memberikan penyuluhan kesehatan tentang rokok dan bahayanya.

\section{METODE PENELITIAN}

Penelitian ini merupakan jenis penelitian kuantitatif dengan metode deskriptif. Populasi terjangkaunya yaitu semua anak sekolah menengah atas pada SMA Petra Sawang Kecamatan Kendahe. Pengambilan sampel pada penelitian ini berdasarkan non-probability sampling dengan menggunakan purposive sampling. Sampel tersebut harus memenuhi kriteria inklusi dan eksklusi. Kriteria Inklusi pada penelitian ini yaitu siswa aktif SMA Petra Sawang Jauh Kecamatan Kendahe dan bersedia menjadi responden. Kriteria eksklusinya yaitu mengundurkan diri sebagai sampel karena alasan tertentu

Sampel yang memenuhi kriteria inklusi dan eksklusi sebanyak 96 siswa. Penelitian telah dilaksanakan di SMA Petra Sawang Jauh Kecamatan Kendahe pada bulan September 2019. Instrumen yang digunakan dalam penelitian ini yaitu kuesioner pengetahuan tentang rokok dan bahayanya. Peneliti menerapkan prinsip etik penelitian yaitu self determination, privacy dan anonymity, confidentially, protection and discomfort, justice (Polit,2012).

Peneliti telah memberikan informasi kepada responden terkait tujuan, manfaat serta keterlibatan responden. Memberikan kebebasan kepada responden untuk terlibat dalam penelitian ataukah tidak. Peneliti telah memberikan informed consent kepada responden untuk ditandatangani serta menjaga privasi responden semaksimal mungkin. Peneliti telah menjaga kerahasiaan identitas responden dan informasi yang diberikan oleh responden. Peneliti telah mencegah atau meminimalkan kerugian dari bahaya yang dapat terjadi serta meningkatkan manfaat bagi semua responden. Peneliti telah menjamin integritas etika dari proses penelitian. Peneliti telah menerapkan keadilan dimana peneliti memberikan perlakukan yang sama pada setiap responden.

Pada penelitian ini analisis data dilakukan dengan analisis univariat pada variabel tunggal pengetahuan siswa tentang rokok dan bahayanya. Analisis disajikan dalam bentuk frekuensi dan presentasi.

\section{HASIL DAN PEMBAHASAN}

Tabel 1. Distribusi Frekuensi variabel independent $(n=96)$

\begin{tabular}{lcc}
\hline Variabel independent & $\mathrm{n}$ & $\%$ \\
\hline Usia & 2 & 2,08 \\
14 tahun & 24 & 25,00 \\
15 tahun & 26 & 27,08 \\
16 tahun & 34 & 35,42 \\
17 tahun & 6 & 6,25 \\
18 tahun & 4 & 4,17 \\
19 tahun & & \\
Jenis Kelamin & 49 & 51 \\
Laki-laki & 47 & 49 \\
Perempuan & & \\
Pengetahuan & 75 & 78,13 \\
Baik & 20 & 20,83 \\
Cukup & 1 & 1,04 \\
Kurang & & \\
\hline
\end{tabular}

Pada penelitian ini sebagian besar responden berjenis kelamin laki-laki dengan persentase $51 \%$. 
Hasil penelitian ini sejalan dengan penelitian yang dilaksanakan oleh Akmal, Bagoes \& Priyadi (2017) pada remaja SMA di Kota Bima yang meneliti tentang Sikap Mempengaruhi Niat Berhenti Merokok pada Remaja SMA di Kota Bima dimana jenis kelamin responden mayoritas laki-laki sebanyak 306 responden atau $93.9 \%$ dan jenis kelamin perempuan sebanyak 20 responden atau $6.1 \%$. Hasil penelitian ini berbeda dengan penelitian yang dilakukan oleh Shabir et al (2013). Shabir et al (2013) menyatakan bahwa lebih banyaknya remaja putri yang menjadi responden memberi pengaruh yang besar terhadap hasil pengetahuan yang baik pada penelitian di SMA Negeri 1 Galis.

Responden terbanyak berada pada usia 17 tahun yaitu sebesar $35,42 \%$. Usia di bawah 18 tahun merupakan masa seorang anak menghadapi masa perubahan dan perkembangan (Juliansyah \& Achmad, 2018). Menurut Hurlock (1990) dalam Jahja (2011) membagi masa remaja menjadi 2 bagian yaitu masa remaja awal (13 hingga 16 atau 17 tahun) dan masa remaja akhir (16 atau 17 tahun hingga 18 tahun). Masa remaja merupakan masa transisi (Sary \& Dina, 2014).

Masa remaja memiliki karakteristik yang membedakannya dengan periode perkembangan lainnya, antara lain masa remaja merupakan periode terjadinya banyak perubahan (Aziizah, I Setiawan \& S Lelyana, 2018). Jahja (2011) mengatakan bahwa garis pemisah antara awal dan akhir masa remaja terletak kira-kira di sekitar 17 tahun yaitu usia di mana rata-rata setiap remaja memasuki sekolah menengah tingkat atas. Shabir et al (2013) menyatakan bahwa faktor usia merupakan salah satu penunjang tingginya angka pengetahuan remaja di SMA Negeri 1 Galis.

Pada penelitian ini tidak dilakukan analisis lebih lanjut terkait hubungan antara usia dan jenis kelamin dengan tingkat pengetahuan.

Pada penelitian ini ditemukan sebesar 78,13\% siswa memiliki pengetahuan baik. Hasil penelitian ini sejalan dengan penelitian yang dilakukan oleh Minh
An et al (2013) tentang pengetahuan terkait konsekuensi kesehatan dari merokok tembakau pada orang dewasa di Vietnam di mana penelitian tersebut menemukan bahwa pengetahuan umum tentang risiko kesehatan dari merokok aktif dan pajanan terhadap perokok pasif memiliki pengetahuan baik yaitu masing-masing dengan persentase $90 \%$ dan $83 \%$.

Hasil penelitian ini sejalan juga dengan hasil penelitian Riyadi, Dwi \& Afi (2018) yaitu pengetahuan remaja tentang bahaya rokok mayoritas tinggi sebesar $53 \%$, sedangkan yang tingkat pengetahuannya rendah sebesar 47\%. Riyadi, Dwi \& Afi (2018) menyatakan bahwa berdasarkan hasil uji statistik ada hubungan negatif, yang berarti bahwa semakin tinggi tingkat pengetahuan remaja tentang bahaya merokok, maka akan semakin rendah keinginan remaja untuk berperilaku merokok.

Penelitian yang dilaksanakan Wibawa, Margo \& Merry (2013) pada siswa kelas 3 SMK Negeri 2 Kendal juga menyimpulkan bahwa mayoritas responden yang berpengetahuan sangat baik mengenai rokok yaitu sebanyak 49 responden atau sebesar $66,2 \%)$.

Secara global, terjadi peningkatan konsumsi rokok terutama di negara berkembang (Kemenkes, 2018). Oleh sebab itu pengetahuan tentang rokok merupakan hal yang penting. Pengetahuan kesehatan tentang dampak risiko dari merokok merupakan faktor yang sangat penting untuk memotivasi perokok untuk berhenti merokok (Dawood et al 2016).

Pengetahuan merupakan domain kognitif yang menjadi target utama suatu proses belajar mengajar dan memiliki pengaruh terhadap perilaku merokok remaja karena kesulitan dalam menghentikan kebiasaan merokok akibat dari kecanduan nikotin disebabkan karena perokok merasakan efek bermanfaat dari nikotin (Sary \& Dina, 2014). Pengetahuan merupakan dasar perubahan perilaku seorang individu, dan merupakan salah satu faktor yang memiliki pengaruh pada motivasi seseorang untuk berhenti merokok (Aziizah, I Setiawan \& S Lelyana, 2018). 
Semakin banyak pengetahuan perokok terkait bahaya merokok maka keinginan untuk berhenti merokok akan semakin tinggi karena rokok mempunyai banyak dampak buruk baik untuk diri sendiri maupun orang-orang disekitar perokok, hal tersebut akan menjadi pertimbangan yang besar bagi seorang perokok untuk berhenti dari perilaku merokoknya, sedikit demi sedikit perokok akan mengurangi aktivitas merokoknya dengan dibantu faktor lainnya yang mempengaruhi motivasi untuk berhenti merokok (Aziizah, I Setiawan \& S Lelyana, 2018).

Pada penelitian ini ditemukan sebesar 20,83\% siswa memiliki pengetahuan cukup dan $1,04 \%$ memiliki pengetahuan kurang. Faktor penyebab yang mempengaruhi pengetahuan seseorang salah satunya adalah faktor informasi, karena kurangnya informasi dapat memperlambat pengetahuan yang diperoleh seseorang (Hidayati, Dewi \& Maya, 2019). Oleh sebab itu, kegiatan sosialisasi terkait rokok perlu ditingkatkan sehingga pengetahuan siswa terkait rokok dan bahayanya mengalami peningkatan. Para siswa dapat diberikan pendidikan kesehatan guna meningkatkan pengetahuan.

Hasil penelitian Hidayati, Dewi \& Maya (2019) menyatakan bahwa ada pengaruh sebelum dan setelah dilakukan pendidikan kesehatan terhadap pengetahuan tentang bahaya merokok di sekolah SMA YWKA di Palembang tahun 2019. Penelitian yang dilakukan oleh Ikhsan (2013) menyatakan bahwa sebelum dilakukan pendidikan kesehatan didapatkan kategori cukup baik sebanyak $36.7 \%$, tidak baik $63.3 \%$. Setelah diberikan pendidikan kesehatan jumlahnya menurun yaitu dari kategori cukup baik sebanyak $90.0 \%$, tidak baik $10.0 \%$ dan secara statistik bermakna $(Z=-4,797 ; p=0,000)$. Pada penelitian Ikhsan (2013) disimpulkan bahwa ada pengaruh yang signifikan antara pendidikan kesehatan bahaya merokok terhadap perilaku mengurangi konsumsi rokok.

Merokok mempengaruhi pertumbuhan fisik dan aktivitas remaja (Uprety et al, 2014) oleh karenanya remaja perlu memilih untuk berperilaku tidak merokok.
Mengingat bahaya tersebut maka diperlukan upaya meningkatkan pengetahuan. Sekolah harus memberikan pendidikan tentang tembakau dan Undang-Undang Produk Tembakau kepada siswa dan juga guru (Htin Aung Myint et al, 2019).

\section{KESIMPULAN}

Pengetahuan siswa tentang rokok dan bahayanya di SMA Petra Sawang Jauh berada pada kategori baik.

\section{Saran}

Bagi guru-guru di sekolah agar memberikan pendidikan kesehatan terkait rokok. Bagi peneliti selanjutnya yaitu melakukan penelitian tentang hubungan pengetahuan tentang rokok dengan perilaku merokok pada kalangan remaja.

\section{DAFTAR RUJUKAN}

Akmal, Dzul., Bagoes Widjanarko \& Priyadi Nugraha. 2017. Sikap Mempengaruhi Niat Berhenti Merokok pada Remaja SMA di Kota Bima. Jurnal Promosi Kesehatan Indonesia, 12 (1)

Aziizah, Karina Nuur., Ignatius Setiawan \& Shelly Lelyana. 2018. Hubungan Tingkat Pengetahuan Tentang Dampak Rokok Terhadap Kesehatan Rongga Mulut dengan Tingkat Motivasi Berhenti Merokok pada Mahasiswa Universitas Kristen Maranatha. SONDE (Sound of Dentistry), 3 (1), 16-21

Badan Narkotika Nasional Republik Indonesia. 2013. Rokok Gerbang Narkoba. Diakses pada tanggal $23 \quad$ April 2019 https://bnn.go.id/blog/artikel/rokok-gerbangnarkoba/

Badan Penelitian dan Pengembangan Kesehatan. 2018. Hasil Utama RISKESDAS 2018. Jakarta : Kementerian Kesehatan RI

Chandra, Winoto. 2014. Dampak Merokok Terhadap Prestasi Belajar Siswa SMA di Palembang. Prosiding Seminar Nasional Inovasi dan Tren (SNIT). Hal D-19

Dawood, Omar Thanoon., Mohammed Abd Ahmed Rashan, Mohamed Azmi Hassali, and Fahad Saleem. 2016. Knowledge and perception about health risks of cigarette smoking among Iraqi smokers. Journal of pharmacy \& bioallied sciences, 8(2), 146-151 
Dinas Kesehatan kabupaten Kepulauan Sangihe. 2017. Profil Kesehatan Kabupaten Kepulauan Sangihe Tahun 2017

Doppy Andika, Oea Khairsyaf \& Dian Pertiwi. 2016. "Hubungan Pengetahuan Dengan Kejadian Merokok Pada Pelajar SMPN 1 Pariaman”. Jurnal Kesehatan Andalas, 5 (2)

Fajar, Rahmat. 2011. Bahaya Merokok. Jakarta: Sarana Bangun Pustaka.

Hidayati , Indah Riski., Dewi Pujiana \& Maya Fadillah. 2019. Pengaruh Pendidikan Kesehatan Terhadap Pengetahuan Dan Sikap Siswa Tentang Bahaya Merokok Kelas XI SMA Yayasan Wanita Kereta Api Palembang Tahun 2019. Jurnal Kesehatan, 12 (2), 125135

Htin Aung Myint, Myat Noe., Eiko Yamamoto, Min Htet Ko, Moe Khaing, Joshua A. Reyer, and Nobuyuki Hamajima. 2019. Knowledge, attitude, and usage pattern of tobacco among high school students in Nay Pyi Taw, Myanmar. Nagoya journal of medical science, 81(1), 65-79.

Husaini, Aiman. 2007. Tobat Merokok. Depok: Pustaka Iman

Ikhsan, Henridha. (2013). Pengaruh Pendidikan Kesehatan Bahaya Merokok Terhadap Perilaku Mengurangi Konsumsi Rokok Pada Remaja (Studi Kasus di Dukuh Kluweng Desa Kejambon Kecamatan Taman Kabupaten Pemalang). Karya Ilmiah STIKES Telogorejo, 2

Jahja, Yudrik. (2011). Psikologi Perkembangan. Jakarta : Prenadamedia Group

Juliansyah, Elvi \& Achmad Rizal. 2018. Faktor Usia, Pendidikan, dan Pengetahuan dengan Perilaku Merokok Di Wilayah Kerja Puskesmas Sungai Durian, Kabupaten Sintang. Visikes Jurnal Kesehatan Masyarakat, 17 (1)

Kementerian Kesehatan RI. 2018. Situasi Umum Konsumsi Tembakau di Indonesia. Jakarta: Infodatin Kemenkes RI

Maseda, Devita Rosalin., Baithesda Suba \& Djon Wongkar. (2013). Hubungan Pengetahuan Dan Sikap Tentang Bahaya Merokok Dengan Perilaku Merokok Pada Remaja Putra di SMA Negeri I Tompasobaru. ejournal Keperawatan $(e-K p), 1$ (1)
Minh An, Dao Thi., Hoang Van Minh, Le Thi Huong, Kim Bao Giang, Le Thi Thanh Xuan, Phan Thi Hai, Pham Quynh Nga, and Jason Hsia. 2013. Knowledge of the health consequences of tobacco smoking : a cross-sectional survey of Vietnamese adults. Global health action, 6, 1-9.

Rachmat, Muhammad., Ridwan Mochtar \& Muhammad Syafar. 2013. Perilaku Merokok Remaja Sekolah Menengah Pertama. Jurnal Kesehatan Masyarakat Nasional. 7 (11).

Riyadi, Sujono., Dwi Yati \& Afi Lutfiyati. 2018. Hubungan Karakteristik Dan Pengetahuan Remaja Tentang Rokok Dengan Perilaku Merokok Remaja Di Kulonprogo Yogyakarta. Jurnal Kesehatan "Wiraraja Medika”, 8 (1)

Sary, Lolita \& Dina Dwi Nuryani. 2014. Hubungan Faktor Interpersonal Dengan Komitmen Pencegahan Tersier Pada Siswa Perokok Di Kota Bandar Lampung Tahun 2013. Jurnal Kesehatan Holistik, 8 (4), 167-173

Shabir, Friandany Natakusuma., Abu Bakar \& Sukma Randani Ismono. (2013). Pengetahuan Bahaya Rokok dan Tindakan Merokok pada Remaja di SMA Negeri 1 Galis Pamekasan. Critical Medical and Surgical Nursing, 1 (2)

Uprety, Samyog., IS Poudel, Sailes Bhattarai, Anup Ghimire, N Singh, Masum Poudel, RB Rayamajhi and Paras Pokharel. 2014. Knowledge On Health Effects And Practices Of Smoking Among The Smokers In Eastern Terai Region Of Nepal. Journal of Chitwan Medical College, 4, 22-25.

Widati, Sri. 2013. Efektivitas Pesan Bahaya Rokok Pada Bungkus Rokok Terhadap Perilaku Merokok Masyarakat Miskin. Jurnal Promkes, 1, 105-110.

Wibawa, Diky Sukma., Margo Utomo \& Merry Tiyas Anggraini. 2013. Hubungan Antara Pengetahuan, lingkungan Sosial, dan Pengaruh Iklan Rokok dengan Frekuensi Merokok. Jurnal Kedokteran Muhammadiyah, $1(2)$ 
Umboh dan Medea, Gambaran Pengetahuan Siswa Tentang...50 